\title{
Aktív eutanázia vagy asszisztált öngyilkosság?
}

\author{
Julesz Máté dr. \\ Szegedi Tudományegyetem, Igazságügyi Orvostani Intézet, Szeged
}

\begin{abstract}
Bevezetés: Az aktív eutanázia és az asszisztált öngyilkosság is törvényes Hollandiában, Belgiumban, Luxemburgban és legújabban Kanadában is. Célkitüzés: Olyan országok vizsgálata, ahol mind az aktív eutanázia, mind az asszisztált öngyilkosság törvényes. A vizsgált országokban elvégzett aktív eutanáziák, valamint asszisztált öngyilkosságok számának alakulása. Módszer: Nemzeti statisztikai adatok elemzése. A 2010-es évekre vonatkozó adatok összevetése a korábban mért számadatokkal. Ezek alapján a vizsgálat tárgyát képező országok gyakorlatának összehasonlítása. Eredmények: Az aktív eutanáziák száma jóval meghaladja az asszisztált öngyilkosságok számát. A rák az aktív eutanázia, valamint az asszisztált öngyilkosság fó oka. A kisebb lélekszámú országokban arányosan kevesebb aktív eutanáziára kerül sor, mint a nagyobb lélekszámú országokban. Következtetések: Tekintettel arra, hogy aktív eutanázia esetén kevésbé valószínú, hogy a beteg visszalép, mint asszisztált öngyilkosság esetén, a betegek - azon országokban, ahol lehet választani - az aktív eutanáziát preferálják. A friss jogalkotási termék miatt egyelőre nincsenek statisztikai adatok a Kanadában elvégzett aktív eutanáziák és asszisztált öngyilkosságok számáról, de a kanadai szabályozás nyomán is kialakul majd valamiféle preferencia az aktív eutanázia és az asszisztált öngyilkosság között. Orv. Hetil., 2016, 157(40), 1595-1600.
\end{abstract}

Kulcsszavak: aktív eutanázia, asszisztált öngyilkosság, Hollandia, Belgium, Luxemburg, Kanada, emberi jogok, orvosi jog

\section{Active euthanasia, or assisted suicide?}

Introduction: Both active euthanasia and assisted suicide are legal in The Netherlands, Belgium, Luxemburg and, most recently, in Canada. Aim: Examination of national legislations of countries where both active euthanasia and assisted suicide are legal. The number of accomplished active euthanasia cases and that of assisted suicide cases. Method: Analysis of national statistical data. Comparison of statistical data before and after 2010. Comparison of the related practices in the surveyed countries. Results: The number of active euthanasia cases markedly predominates over the number of assisted suicide cases. Cancer is a main reason for active euthanasia, or assisted suicide. In countries with a larger population, the number of active euthanasia cases is higher than that in countries with a smaller population. Conclusions: Regarding the fact that the applicants for active euthanasia withdraw their requests in a smaller number than the applicants for assisted suicide, patients prefer the choice of active euthanasia. Since the related legislative product is too recent in Canada at present, it may be only presumed that a certain preference will also develop in the related practices in Canada.

Keywords: active euthanasia, assisted suicide, The Netherlands, Belgium, Luxemburg, Canada, human rights, medical law

Julesz, M. [Active euthanasia, or assisted suicide?]. Orv. Hetil., 2016, 157(40), 1595-1600.

(Beérkezett: 2016. július 6.; elfogadva: 2016. július 26.)

\section{Seneca orvos által asszisztált öngyilkossága}

Az ókori Rómában széles körben virágzott az öngyilkosság kultúrája. Például Seneca vagy Petronius Arbiter is öngyilkossággal halt meg. Seneca Kr. u. 65-ben vágta fel ereit, míg Petronius Arbiter Kr. u. 66-ban tette ugyanezt. Az öngyilkosság kultúrája főleg arra terjedt ki, hogy az uralkodóval összekülönböző költők és bölcselők, valamint a római közélet más, köztiszteletben álló tagjai így mentsék meg önmaguk és császáruk jó hírét attól, hogy 
másnak kelljen megölni őket. A mai jogértelmezés szerint az uralkodó így öngyilkosságban közremúködést valósított meg, azonban ezt nem lehetett bizonyítani. Nem eutanáziáról volt szó, de asszisztált öngyilkosságnak lehetne minősíteni, mivel Statius Annaeus, Seneca orvosa tanáccsal és eszközzel - például az érfelvágás után végül még méregpohár átadásával is - segítette Senecát az öngyilkosságban. Seneca önmaga vágta fel ereit és saját akaratelhatározásából itta ki a méregpoharat. Mindezt Tacitus történetírásából tudjuk [1].

Seneca orvos által asszisztált öngyilkossága a mai kor fejlett jogrendszerei szerint nem lenne kivitelezhető. Ugyanakkor Seneca példája az ókorba visz vissza minket. Látjuk, hogy az asszisztált öngyilkosság nem volt idegen az ókori embertől. Mindazonáltal mai fogalmaink szerint a mégoly fejlett római jogú birodalom sem minősülne demokratikus jogállamnak.

Az öngyilkosság legalizálását a XX. század jogalkotása már elvégezte. Ma már a legtöbb országban etikai és nem jogi kérdés, hogy egy individuum elveheti-e önnön életét. A társadalom és a jogalkotó vitája arra fókuszál, hogy jogi és etikai szempontból megengedhető-e, hogy egy másik személy végezze el az ölést, vagy hogy egy másik személy segítséget nyújtson az öngyilkossághoz. Az értékek pluralitása mentén el kell fogadnunk, hogy vannak államok, amelyek szembemennek a legnagyobb világegyházak tanításával, és legalizálják az aktív eutanáziát vagy az orvos által asszisztált öngyilkosságot. A lelkiismereti és vallásszabadságot ezen államok is biztosítják polgáraik számára. Tehát a kiterjesztett egészségügyi önrendelkezési jog nem jelenti, hogy a polgároknak kötelező lenne részt venni az aktív eutanáziában vagy az aszszisztált öngyilkosságban:

- egyrészt ezen államokban a polgár szabad döntése, hogy kéri-e;

- másrészt ezen államokban az orvos dönthet úgy a lelkiismerete, illetve a vallása parancsa szerint, hogy nem vesz részt benne.

Kereszty Éva írta „Halottak, akik köztünk élnek” című, 2006-ban megjelent könyvében: „Saját igazságügyi orvosi gyakorlatomban és a kollégák elmondása szerint néhány éve is előfordult - még ha ritkán is -, hogy a hozzátartozók mindenáron azt kérték volna, hogy a halottvizsgálati bizonyítvány »balesetet «, ne pedig »öngyilkosságot « tartalmazzon, illetve adjunk igazolást vagy tüntessük fel bonctani alapdiagnózisként a súlyos tudatzavart.” A szerző ennek okát abban látja, hogy Magyarországon - ahogy sok más országban is - a társadalom és az egyházak negatívan ítélik meg az öngyilkosságot [2].

Hámori Antal az eutanázia fogalmát úgy határozza meg, hogy „a 'halál közeli' állapotban lévő másik ember (beteg) 'minden' fájdalma (szenvedése) megszüntetésének, illetve csökkentésének szándékával, saját kérésre, beleegyezéssel vagy annak hiányában történő (lásd például kómában lévő beteg), a betegség természetes lefolyását lehetővé nem tevő, vagy a 'kettős hatás' elvét egyébként sértő (orvos általi) szándékos megölése". Hámori
Antal az asszisztált öngyilkosságot „az eutanázia különleges formája”-ként jelöli meg [3].

\section{Emberi jogok és aktív eutanázia/asszisztált öngyilkosság}

Magyarországon az Alkotmánybíróság 64/1991. (XII. 17.) AB határozata - egyebek mellett - megfogalmazta, hogy az eutanázia alkotmányossága eldönthető az élethez és emberi méltósághoz való jog értelmezése alapján, anélkül, hogy az ember formális jogi fogalmát szükségszerúen érinteni kellene. Az Alkotmánybíróság álláspontja szerint az egyes országokban létezô eutanáziaszabályozás értelmében az individuális ismérvek alapján (bűnösség, életminőség, tudati, illetve fizikai állapot) a sajátosan emberi jogállást megalapozó jogok elvonhatók, illetve korlátozhatók. Az eutanázia alapkérdése eszerint az élethez és méltósághoz való jog feltétlensége vagy korlátozhatósága. Magyarországon az Alkotmánybíróság 2010-ben kelt $87 / \mathrm{B} / 2004$. AB határozata úgy fogalmazott, hogy az élethez való jog védelme elválik az egészséghez való jog védelmétől. Az élethez való jog sérelme azon jogintézmények, jogi szabályozások tekintetében merül fel, amelyek - az adott jogintézmény természetéból fakadóan, illetve szabályozások alkalmazása folytán - okszerúen magukban hordozzák az emberi élet elvételének lehetőségét. Erre példaként az AB határozat az aktív eutanázia mellett a halálbüntetést és a lőfegyverhasználatot hozza fel. Nem kimerítő felsorolásról van szó, de a felhozott példák közül a halálbüntetést és az aktív eutanáziát érdemes párhuzamba állítanunk. A halál - mint végső állapot - nem fordítható vissza. A halál mesterséges előidézése valóban nem biztos, hogy az egészséghez való jog és az egészségügyi önrendelkezéshez való jog része. Az élethez való jog emberi jog, amelyról azonban a beteg - éppen betegsége és szenvedése okán - számos esetben lemondana. Hogy a halálhoz való jogot milyen terjedelemben engedi meg a jogalkotó a beteg számára, az a jogalkotót legitimáló társadalom kívánalmaitól függ.

Európában csak Svájcban és 2015. december 10. óta Németországban legális az asszisztált öngyilkosság. Hollandiában, Belgiumban és Luxemburgban az aktív eutanázia és az asszisztált öngyilkosság is törvényes. Mivel sem európai uniós, sem Európa Tanács-szintű kötelezés vagy tiltás nincs ebben a kérdésben, a törvényhozó hatalom a polgárok legitimáló erejével bármely európai országban szabadon dönthet úgy, hogy az aktív eutanázia vagy/és az asszisztált öngyilkosság jogintézményét választja, vagy pedig mindkét institúciót tiltja. A Gross versus Svájc ügyben 2013. május 14-én kelt ítéletében az Emberi Jogok Európai Bírósága azért utasította el Alda Gross panaszát, mert az Európa Tanács egyetlen országát sem lehet asszisztált öngyilkosság engedélyezésére kötelezni. Ha Zürich Kanton Egészségügyi Bizottsága mint közigazgatási hatóság elutasította, hogy Alda Grossnak 15 gramm pentobarbitált engedélyezzenek, és 
ezt követően Zürich Kanton Közigazgatási Bírósága is elutasította Alda Gross kérelmét, az Emberi Jogok Európai Bírósága e téren nem szólhat bele a svájci rule of law alkalmazásába. (67810/10. számú kérelem.) Az Emberi Jogok Európai Bírósága már egy korábbi ítéletében, 2011-ben, a Haas versus Svájc ügyben szintén Svájc belügyének tekintette, hogy nem engedélyezett asszisztált öngyilkosságot a panaszosnak. (31322/07. számú kérelem.) A svájci szövetségi statisztikai hivatal sokáig nem publikált adatot az asszisztált öngyilkosságok számáról. Végül megtörték a csendet, és közzétették, hogy 2009ben közel 300 asszisztált öngyilkosságra került sor. Ez az összes elhalálozás mintegy fél százaléka. 1998 és 2009 között folyamatosan növekedett az asszisztált öngyilkosságok száma. A betegek 90\%-a 55 év feletti, és mindöszsze 1\%-uk 35 év alatti. Asszisztált öngyilkosságot a legnagyobb számban rákos betegek kérnek (44\%). A rákon kívül idegrendszeri degeneratív, cardiovascularis és mozgásszervi betegségek miatt engedélyeztek asszisztált öngyilkosságot. A 2000-es években megfordult a nemi arány korábbi tendenciája, és már nem a férfiak, hanem a nők kérelmezik nagyobb számban az asszisztált öngyilkosságot [4].

Belgiumban 2013-ban Christian de Duve-ön, az orvosi Nobel-díjat elnyert belga professzoron hajtottak végre aktív eutanáziát, amelynél a családja is jelen volt. A 95 éves orvosprofesszor az eutanázia előtti hónapokban a hozzá legközelebb álló családtagoknak és kutatótársaknak értésükre adta, miért nem várja meg a természetes úton bekövetkező halált: tartott attól, hogy rákos betegsége miatt egy idő után elveszítené döntésképességét. Az önkontroll elvesztése miatti félelem gyakori ok az aktív eutanázia kérelmezésekor, de ekkor is csak gyógyíthatatlan betegségben szenvedőnek szabad engedélyezni.

Hollandiában 2014-ben mintegy 5000 esetben került sor aktív eutanáziára, ami a 2013-as adathoz képest 10\%os növekedést jelentett. Az esetek mintegy 70-80\%-ában rákos betegség miatt került sor aktív eutanáziára. Demencia miatt az esetek mintegy 1-2\%-ában, míg egyéb pszichiátriai betegség miatt mindössze az esetek alig 1\%ában hajtottak végre aktív eutanáziát. Hollandiában 2014-ben a rák miatt elhunytak 9,2\%-a halt meg aktív eutanázia következtében. Az aktív eutanáziát az esetek $90 \%$-ában a beteg háziorvosa hajtotta végre [5]. Belgiumban 2010-ben még 953 aktív eutanáziát regisztráltak, de 2013-ban már 1807-et. A végrehajtott aktív eutanáziák száma Belgiumban is fokozatosan növekszik: tehát négy év alatt $89 \%$-kal. Az esetek elenyésző hányadában vezetett pszichiátriai betegség aktív eutanáziához. A betegek 75\%-a 60-89 éves volt. Belgiumban a Commission de contrôle et d'évaluation (kontroll- és értékelőbizottság) néhány tagja a 2013. évi bizottsági jelentés szerint sérelmezte, hogy visszafordíthatatlan tudatvesztéskor csak kóma esetén alkalmazzák az aktív eutanáziát. Szerintük az irreverzibilis tudatvesztést tágabb értelemben kellene felfogni, amikor az aktív eutanázia alkalmazhatóságáról döntenek, és így több esetben lehetne engedé- lyezni az aktív eutanáziát [6]. Az aktív eutanázia a Benelux államok közül Luxemburgban került bevezetésre a legkésóbb: 2009-ben hirdették ki az eutanáziatörvényt. 2014-ig összesen 34 aktív eutanáziát hajtottak végre, tehát a Luxemburgban bekövetkezett elhalálozások 0,196\%-a történt aktív eutanázia következtében [7].

Az Emberi Jogok Európai Bíróságának Nagykamarája 2015. június 5-én úgy döntött, hogy jogszerúen, az Emberi Jogok Európai Egyezségokmányát meg nem sértve engedélyezte a francia Conseil d'État (legfelsőbb bíróság), hogy Vincent Lambert életfenntartó kezelését a férfi feleségének kérésére megszüntessék. Vincent Lambert szülei nem értettek egyet a feleség ezen kérelmével, így jutott el az ügy a strasbourgi emberi jogi bíróságig. A férfi még 2008-ban szenvedett közlekedési balesetet, amely után többé nem tért magához. A kezelés korlátozására vagy megszüntetésére irányuló eljárás egy jogszerü lehetőség Franciaországban, de ezt nem tekintik aktív eutanáziának [8]. Németországban szintén nem legális az aktív eutanázia. Az Emberi Jogok Európai Bírósága 2012. július 19-i ítéletében a Koch kontra Németország ügyben kimondta, hogy az Európa Tanács tagállamai szabadon dönthetnek arról, hogy az aktív eutanáziát vagy az asszisztált öngyilkosságot törvényessé teszik-e. Ebbe a strasbourgi emberi jogi bíróság nem szólhat bele. Koch úr felesége egy baleset következtében mind a négy végtagjára megbénult, ezért ahhoz kért engedélyt a német hatóságtól, hogy férje beadhasson neki 15 gramm nátrium-pentobarbitált. Erre nem kapott engedélyt, így végül Svájcban végezték el az asszisztált öngyilkosságot. Koch úr ezt követően az Emberi Jogok Európai Bíróságához fordult, mert álláspontja szerint a német hatóság megsértette feleségének az Emberi Jogok Európai Egyezményének 8. cikkelyében foglalt, a magánélet és a családi élet szentségéhez füződő jogát. Az Emberi Jogok Európai Bírósága csak azért marasztalta el Németországot, mert a német igazságszolgáltatás nem vizsgálta meg érdemben Koch úr keresetét, mielőtt elutasította azt, és így nem tette lehetôvé, hogy Koch úr érdemben kimeríthesse a hazai igazságszolgáltatás lehetőségeit, mielőtt a strasbourgi emberi jogi bírósághoz fordult [9].

Amennyiben a magyar törvényhozás úgy döntene, hogy legalizálja az aktív eutanáziát vagy az orvos által asszisztált öngyilkosságot, annak eseti ügyekben való alkalmazásába semmilyen nemzetközi jogi fórumon nem lehetne beleszólni, mivel jelenleg nincs olyan nemzetközi jogi dokumentum, amelynek alapján valamely államot akár kötelezni lehetne rá, akár eltiltani lehetne attól, hogy aktív eutanáziát vagy asszisztált öngyilkosságot engedélyezzen, vagy ne engedélyezzen a polgárainak. Magyarországon ma nincs napirenden az aktív eutanázia vagy az asszisztált öngyilkosság törvényessé tétele, és ez a közeli jövőben sem várható. Ennek egyik alapvető oka, hogy a lakosság többsége elutasítja, hogy az egészségügyi önrendelkezési jog ilyen kiterjesztő értelmezést kapjon. A passzív eutanázia legalizálása is csak két évtizedre nyúlik vissza a magyar jogtörténetben. A passzív 
eutanázia lényegesen távolabb áll az aktív eutanáziától, mint az asszisztált öngyilkosság az aktív eutanáziától. A távolság az élet tevőleges elvételében nyilvánul meg. Míg passzív eutanázia esetén nem tevéssel valósul meg az élet elvétele, addig aktív eutanázia esetén az orvos tevőlegesen hajtja végre az élet elvételét. Asszisztált öngyilkosság esetén az orvos szintén tevőlegesen múködik közre a beteg öngyilkosságában. A tevőlegesség és a nem tevés a lakosság jogérzetében óriási különbséget jelent. Tenni azért, hogy a szenvedő beteg élete nem természetes úton érjen véget, a magyar lakosság többsége számára nem pusztán jogilag, de etikailag is helytelen. Nem tenni azért, hogy a halála közelébe ért beteg életét meghoszszabbítsák, humánus és etikai szempontból könnyebben elfogadható, ezért a magyar törvényhozás is kizárólag ez utóbbit legalizálta.

\section{Aktív eutanázia és asszisztált öngyilkosság Kanadában}

A friss jogalkotási termék miatt egyelőre nincsenek statisztikai adatok a Kanadában elvégzett aktív eutanáziák és asszisztált öngyilkosságok számáról, de a kanadai szabályozás nyomán is kialakul majd valamiféle preferencia az aktív eutanázia és az asszisztált öngyilkosság között.

2015. február 6-án döntött úgy a kanadai legfelsőbb bíróság, hogy bizonyos körülmények fennforgása esetén az orvos nem büntethető aktív eutanázia alkalmazása, illetve asszisztált öngyilkosságban való közremúködés miatt. Ez a Carter kontra Kanada ügyben került megfogalmazásra. A legfelsőbb bíróság kimondta, hogy a kanadai büntető törvénykönyv e tekintetben sérti az 1982. évi kanadai alkotmány 7 . cikkelyében foglalt alapjogot. Az 1982. évi kanadai alkotmány 7. cikkelye szerint mindenkinek joga van az élethez, a szabadsághoz és a biztonsághoz, és mindettől csak akkor fosztható meg, ha ez nem sérti az alapvető igazságosságot (fundamental jus tice). Ekként a kanadai legfelsőbb bíróság az élethez való jogot negatív tartományban is értelmezi: tehát a kanadai polgároknak (és a kanadai egészségbiztosítás kedvezményezettjeinek) nemcsak az élethez, hanem az arról való lemondáshoz és az ehhez nyújtott aktív segítséghez is joguk van. Az életről történő lemondás jogát a Carter kontra Kanada ügyben foglaltak szerint csak súlyos és gyógyíthatatlan betegségben szenvedő felnőttek gyakorolhatják, ha tartós szenvedésük elviselhetetlen [10].

Ettől fogva a kanadai törvényhozás feladata volt eleget tenni a legfelsőbb bíróság által felállított követelménynek. 2016. június 17-én hagyta jóvá az angol királynő a kanadai büntető törvénykönyv azon módosítását, amely szerint a törvényes keretek között végrehajtott aktív eutanázia és asszisztált öngyilkosság esetén az orvos, az egészségügyi szakdolgozó (nővér, ápoló), valamint a mérget kiadó gyógyszerész nem büntethető. A kanadai büntető törvénykönyv 241.1. szakasza határozza meg, hogy mit jelent a medical assistance in dying. Ez alatt érteni kell:
- az aktív eutanáziát, tehát amikor az orvos vagy az egészségügyi szakdolgozó adja be a halált okozó anyagot a betegnek annak kérésére, valamint

- az asszisztált öngyilkosságot, tehát amikor a beteg kérésére az orvos vagy az egészségügyi szakdolgozó halált okozó anyagot ír fel, illetve nyújt át a betegnek, de azt a beteg saját magának adja be.

A kanadai Btk. 241.2. szakaszának (1) bekezdése értelmében ahhoz, hogy a betegen az aktív eutanáziát vagy az asszisztált öngyilkosságot végre lehessen hajtani, a beteg a következő kritériumoknak kell, hogy megfeleljen (konjunktív feltételek):

- a beteg jogosult legyen Kanadában az egészségbiztosítás szolgáltatásaira (tehát kanadai állampolgár vagy Kanadában lakóhellyel rendelkező polgár legyen);

- betöltötte a 18. életévét és teljes mértékben bír az egészségügyi önrendelkezés jogával;

- súlyos és gyógyíthatatlan betegségben szenved;

- önként, minden külső kényszer hatása nélkül kérje az aktív eutanáziát vagy az asszisztált öngyilkosságot;

- a beteg tájékozott beleegyezését adja az aktív eutanáziához vagy az asszisztált öngyilkossághoz azt követően, hogy informálták a fájdalomcsillapítás és a palliatív terminális medicina lehetőségeiről.

A kanadai büntető törvénykönyv 241.2. szakaszának (2) bekezdése értelmében súlyos és gyógyíthatatlan betegségnek minősül (konjunktív feltételek):

- a súlyos és nem gyógyítható testi vagy lelki betegség és fogyatékosság;

- a beteg előrehaladott és vissza nem fordítható állapotban van;

- a betegség vagy a fogyatékosság elviselhetetlen és hosszan tartó testi vagy/és lelki szenvedést okoz a betegnek, ami nem enyhíthető;

- a természetes halál ésszerüen előrelátható időn belül be fog következni.

Az aktív eutanázia, illetve az asszisztált öngyilkosság elvégzése előtt az orvosnak, illetve az egészségügyi szakdolgozónak

- meg kell győződnie arról, hogy a kérelmező beteg megfelel a törvényi követelményeknek;

- meg kell győződnie arról, hogy a beteg írásban nyújtotta be a kérelmét, és azt aláírta és keltezte; vagy, ha nem képes rá, akkor egy 18. életévét betöltött és a beteg után nem öröklő és vagyoni előnyből más módon - mint például biztosítási szerződés kedvezményezettjeként - sem részesülő személy írta alá és keltezte a beteg nevében, a beteg jelenlétében és a beteg kifejezett kívánatára;

- meg kell győződnie arról, hogy a kérelem aláíását megelőzően az orvos vagy az egészségügyi szakdolgozó tájékoztatta a beteget a betegsége súlyos és gyógyíthatatlan jellegéról;

- meg kell győződnie arról, hogy a kérelmet két tanú előtt írták alá, és a tanúk is aláírták és dátumozták; 
- meg kell győződnie arról, hogy a beteget tájékoztatták, hogy kérelmét bármikor és bármilyen formában visszavonhatja;

- meg kell győződnie arról, hogy a kérelem törvényi feltételeinek fennállását egy másik, tőle független orvos vagy egészségügyi szakdolgozó is írásban tanúsította;

- meg kell győződnie arról, hogy a kérelem aláirása és az aktív eutanázia, illetve az asszisztált öngyilkosság végrehajtása között legalább tíz nap telt el; ennél rövidebb időt az orvos, illetve az egészségügyi szakdolgozó akkor fogadhat el, ha a beteg halála természetes úton hamarabb következne be;

- közvetlenül az aktív eutanázia, illetve az asszisztált öngyilkosság előtt lehetőséget kell adnia a betegnek, hogy visszavonja a kérelmét, és csak az ekkor megerősített kérelem esetén végezhető el az aktív eutanázia, illetve az asszisztált öngyilkosság;

- biztosítania kell, hogy a kommunikációs nehézséggel küzdő beteg megértse az állapotát, és ennek megfeleló döntést hozzon.

Tanú csak az lehet, aki betöltötte a 18. életévét és világosan érti, hogy mit jelent a kérelmezett aktív eutanázia, illetve az asszisztált öngyilkosság. Nem lehet tanú, aki tudja vagy gondolja, hogy a beteg halála után annak örököse lenne vagy más módon vagyoni előnyhöz jutna (például biztosítási szerződés kedvezményezettjeként). Nem lehet tanú, aki a beteget kezelő intézmény vagy bentlakásos szociális otthon tulajdonosa vagy üzemeltetője. Nem lehet tanú, aki a beteg aktív eutanáziájában vagy asszisztált öngyilkosságában közvetlenül részt vesz, továbbá az sem, aki a beteg kezelésében közvetlenül részt vesz.

Az aktív eutanázia, illetve az asszisztált öngyilkosság elvégzése előtt az orvosnak, illetve az egészségügyi szakdolgozónak meg kell győződnie arról, hogy a kérelem törvényi feltételeinek fennállását egy másik, tőle független orvos vagy egészségügyi szakdolgozó is írásban tanúsította. A függetlenség azt jelenti, hogy az orvosok vagy egészségügyi szakdolgozók sem szakmai irányítási, sem felügyeleti jogviszonyban nem állnak egymással. A függetlenség anyagi függetlenséget is jelent: tehát semmilyen vagyoni előnyhöz nem juthatnak a beteg halála folytán. Az aktív eutanázia, illetve az asszisztált öngyilkosság mint egészségügyi szolgáltatás díját föszabály szerint a beteg fizeti, de a halálos gyógyszer költségét az állami egészségbiztosítás állja. A függetlenség további követelménye a tárgyilagos (szubjektivitástól mentes) döntéshozatal [11].

Az aktív eutanáziát, illetve az asszisztált öngyilkosságot az orvosnak, illetve az egészségügyi szakdolgozónak lege artis medicinae, tehát az orvosi szakma professzionális szabályai, valamint a jogszabályok betartásával kell elvégezni. A kanadai büntető törvénykönyv 241.2. szakaszának (8) bekezdése értelmében az orvosnak, illetve az egészségügyi szakdolgozónak előzetesen, tehát mielőtt a gyógyszerész kiadná a halált okozó gyógyszert, tájékoztatnia kell a gyógyszerészt arról, hogy az aktív eutanázia, illetve asszisztált öngyilkosság céljából szükséges.

A kanadai Btk. 241.2. szakaszának (9) bekezdése megadja a lehetőséget az orvosnak, az egészségügyi szakdolgozónak, a gyógyszerésznek, valamint a tanúknak és a beteg helyett aláíó személynek, hogy megtagadják az aktív eutanáziában, illetve asszisztált öngyilkosságban való bármiféle részvételt. Ebben az esetben az érintett tájékoztatja a munkahelyi vezetőt, aki más személyt kér fel. Tehát mindenképpen biztosítani kell, hogy más segítsen megvalósítani a beteg kérelmét.

A kanadai büntető törvénykönyv arra is kitér, miként kell büntetőjogilag minősíteni, ha az orvos vagy az egészségügyi szakdolgozó úgy hajt végre aktív eutanáziát vagy asszisztált öngyilkosságot, hogy nem tart be minden törvényi feltételt: öt évig terjedő szabadságvesztést, vagy tárgyalásról lemondás, illetve tárgyalás mellőzése esetén másfél évig terjedő szabadságvesztést lehet kiszabni. Ugyanez a büntetési tétele annak, aki aktív eutanáziával vagy asszisztált öngyilkossággal kapcsolatos okiratot hamisít vagy megsemmisít. Az okirat megsemmisítése ebben az esetben csak akkor büntetendő, ha abból a célból teszik, hogy

- a beteg aktív eutanáziához, illetve asszisztált öngyilkossághoz való jogának gyakorlását megakadályozzák; vagy

- a beteg kérelmének jogszerú elbírálását befolyásolják; vagy

- az aktív eutanáziában, illetve asszisztált öngyilkosságban részt vevő valamely személyt jogellenesen vonjanak büntetőjogi felelősségre.

Kanada tagállamai tagállami szintű szabályozásokat vezettek be, amelyekben meghatározzák, miként kell végrehajtani az immár az egész országban legális aktív eutanáziát, illetve asszisztált öngyilkosságot. Például Alberta államban az Albertai Egészségügyi Szolgálat (Alberta Health Services) köteles biztosítani a polgárok számára ezt a jogi lehetőséget. Az egészségügyi szolgálat valamely egészségügyi szolgáltatónál vagy a meghalni vágyó lakhelyén gondoskodik az aktív eutanázia, illetve az asszisztált öngyilkosság végrehajtásáról. Az Albertai Egészségügyi Szolgálat gondoskodik az aktív eutanáziában és asszisztált öngyilkosságban részt vevő orvosok és egészségügyi szakdolgozók szakmai és jogi ismereteinek fejlesztéséről: kidolgozza a helyes klinikai gyakorlatot az orvosok és egészségügyi szakdolgozók számára. British Columbia államban az aktív eutanáziát/asszisztált öngyilkosságot végző orvosnak a College of Physicians and Surgeons of British Columbia, azaz British Columbia orvosi és sebészi kollégiumának a vonatkozó irányelveit kell betartania. Ezek az irányelvek Kanadán belül tagállamonként némiképp eltéróek lehetnek. Albertában az aktív eutanáziában, illetve asszisztált öngyilkosságban közremúködést vállaló egészségügyi szolgáltatónak első lépésben meg kell ismernie az albertai Medical Assistance in Dying Care Coordination Service vonatkozó irányelveit. A gyógyszerész kizárólag az Alberta College of 
Pharmacists (albertai gyógyszerészeti kollégium) által kibocsátott listán megtalálható gyógyszert adhat ki aktív eutanázia vagy asszisztált öngyilkosság céljából. Az orvos vagy egészségügyi szakdolgozó köteles jelezni a Medical Assistance in Dying Care Coordination Service irányába, ha megkapja a beteg szabályos kérelmét. Az aktív eutanázia és az asszisztált öngyilkosság per definitionem egészségügyi beavatkozásnak minősül. A beteg hozzájárulásával arra is van lehetőség, hogy tudományos vagy oktatási célból tanulmányozzák az aktív eutanázia, illetve az asszisztált öngyilkosság végrehajtását. Tehát például orvostanhallgatók a beteg hozzájárulásával jelen lehetnek az egészségügyi beavatkozás végrehajtásánál. Arra az esetre, ha a beteg nem tudná megfelelően beadni magának az asszisztált öngyilkossághoz kapott gyógyszert, kezelési tervet (treatment plan) kell kidolgozni, hogy az orvos miként avatkozzon be, és hogy adja be a halálos gyógyszert a betegnek. Ekkor az asszisztált öngyilkosság egyik pillanatról a másikra aktív eutanáziába megy át, természetesen a beteg akaratának megfelelóen. Mint minden más egészségügyi beavatkozást, az aktív eutanáziát és az asszisztált öngyilkosságot is megfelelően dokumentálni kell.

$\mathrm{Az}$ orvos szakmai és büntetőjogi felelősségét érinti Filó Mihály 2002-ben a Magyar Jogban tett megállapítása: „Egyértelmű az orvos kezelési kötelezettsége, ha a szuicídium pszichiátriai kórkép tüneteként lép fel. A szabad akaratból elkövetett öndestrukció tekintetében már cselekvőképtelenné vált sértettnél a bírói gyakorlat korábban megkövetelte a feltétlen segítségnyújtást. Ez a kívánalom azonban abszurd helyzetekhez vezethet, ugyanis így tétlenül nézhetnénk azt, ahogy halálraszánt embertársunk felakasztja magát, azonban ha mindeközben eszméletét is veszíti, büntetőjogi felelősségre vonással kell számolnunk, ha nem próbáljuk megmenteni” [12].

Québec államban a Commission sur les soins de fin de vie (életvégi gondoskodás bizottsága) ügyel az aktív eutanázia és az asszisztált öngyilkosság törvényi kereteinek betartására. Nem megfelelő eljárás esetén a beteg az egészségbiztosítóhoz tartozó egészségügyi szolgáltatóval (például állami kórházzal) szemben panaszt nyújthat be a Complaints and Service Quality Commissioner-höz. Magán-egészségügyi szolgáltató (például magánorvos, magánklinika) ellen a panaszt a Collège des médecins $d u$ Québec-hez kell benyújtani. A jogbiztonságot Kanada a demokratikus rule of law maximális biztosításával nyúitja.

Az aktív eutanáziát Kanadában living will, azaz éló végakarat formájában is lehet kérni. Ez azt jelenti, hogy a beteg előre jognyilatkozatot tesz, amelyben kéri, hogy ha már nem lesz cselekvő́képes és az aktív eutanázia tör- vényi feltételei fennállnak, hajtsák végre rajta az aktív eutanáziát.

Minden egészségügyi szolgáltatónál kell lennie egy felelős személynek, akit az intézmény vezetője arra jelöl ki, hogy az aktív eutanázia, illetve az asszisztált öngyilkosság iránt érdeklődőknek adekvát felvilágosítást adjon. Ezzel megkímélik a betegeket a felelősségáthárító „pingpongozástól”. Az egészségügyi önrendelkezés jogát Kanada minden polgárának a lehető legteljesebb mértékben biztosítja.

Anyagi támogatás: A közlemény megírása anyagi támogatásban nem részesült.

A szerző a cikk végleges változatát elolvasta és jóváhagyta.

Érdekeltségek: A szerzőnek nincsenek érdekeltségei.

\section{Irodalom}

[1] Tacitus, C. C.: Annales. 1st century AC. [Évkönyvek.] Tankönyvkiadó, Budapest, 1970. [Hungarian]

[2] Kereszty, É.: Dead people who live with us. [Halottak, akik köztünk élnek.] Medicina Könyvkiadó, Budapest, 2006. [Hungarian]

[3] Hámori, A.: On the notion of 'euthanasia'. [Az „eutanázia” fogalmához.] Magyar Jog, 2010, 57(9), 561-568. [Hungarian]

[4] Premiers chiffres officiels sur l'assistance au suicide en Suisse 2012. http://www.rts.ch/info/suisse/3884432-premiers-chiffres-officiels-sur-l-assistance-au-suicide-en-suisse-.html

[5] Cijfers euthanasie oktober 2015. https://www.rijksoverheid.nl/ documenten/rapporten/2016/01/09/cijfers-euthanasie

[6] Rapport de la Commission d'évaluation euthanasie 2014. http://www.ieb-eib.org/fr/document/rapport-de-la-commission-devaluation-euthanasie-2014-380.html

[7] Le salon beige 2015. http://lesalonbeige.blogs.com/my_ weblog/2015/04/-leuthanasie-au-luxembourg.html

[8] Grande Chambre - Affaire Lambert et autres contre France (requête no. 46043/14) - Arrêt Strasbourg 5 juin 2015. https://www.verein-eras.ch/uploads/files/pdf/AFFAIRELAMBERT-ET-AUTRES-FRANCE.pdf

[9] Arrêt Koch contre Allemagne du 19 juillet 2012 (requête no. 497/09). http://www.ieb-eib.org/fr/document/affaire-kochc-allemagne-suicide-assiste-333.html

[10] Carter versus Canada (Attorney General), [2015] I SCR 331, 2015 SCC 5 (Can LII). https://scc-csc.lexum.com/scc-csc/ scc-csc/en/item/14637/index.do

[11] Julesz, M.: Euthanasia outside Europe. [Eutanázia Európán kívül.] Orv. Hetil., 2014, 155(32), 1259-1264. [Hungarian]

[12] Filó, M.: Euthanasia in the German criminal law. [Az eutanázia a német büntetőjogi gondolkodásban.] Magyar Jog, 2002, 49(8), 478-484. [Hungarian]

(Julesz Máté dr., Szeged, Szentháromság u. 20., 6722 e-mail: mate.julesz@freemail.hu) 